\title{
Fostering the growth of TPACK among international teachers of developing nations through a cultural exchange program
}

\author{
Medha Dalal \\ Arizona State University, USA \\ Leanna Archambault \\ Arizona State University, USA \\ Catharyn Shelton \\ Northern Arizona University, USA
}

\begin{abstract}
This study investigated the impact of a semester-long technology course as part of a higher education cultural exchange program for secondary school teachers of developing nations. We integrated quantitative data from surveys that evaluated participants' technological pedagogical content knowledge (TPACK), with qualitative evidence from participants' technology-based lesson designs. Analysis across the 16 participants indicated that the course was effective in improving teachers' TPACK. Teachers reported increases in all TPACK domains, with the largest growth in technological content knowledge and TPACK. However, qualitative analysis suggested greater presence of technological pedagogical knowledge. Teachers learned to consider affordances of technology in accordance with content or pedagogy, but their ability was limited due to resource constraints or students' readiness. Results suggest that international exchange programs are a valuable way to support teachers of developing nations in building educational technology capacity at their home schools.
\end{abstract}

Implications for practice or policy:

- Technology education should leverage teacher expertise in pedagogical content knowledge.

- Developers should consider the contexts of home schools when designing education experiences for international teachers.

- Continuing education that gives opportunities for hands-on work (active learning) is an effective way to support development of teachers regarding educational technology.

Keywords: international teachers, TPACK, technology integration, mixed methods, professional development

\section{Introduction}

Embracing the benefits of multicultural learning, many institutes across the world have launched exchange or study abroad programs (McConnell, 2000). Such initiatives may be particularly powerful for teachers of developing nations to think more globally, reach across cultures, and better understand the human experience (Howe \& Xu, 2013). We explored one United States of America (USA) cultural exchange program designed for teachers of developing nations: the International Leaders in Education (ILEP). From 2007 to 2018, the U.S. Department of State implemented ILEP, an exchange program that each year brought 60 exceptional secondary school teachers from select developing nations to the USA for a semester at one of four host universities. As of 2019, ILEP became part of the Fulbright program and is now known as the Fulbright Distinguished Awards in Teaching Program for International Teachers (International Research \& Exchanges Board, 2020). The current study focused on the former program.

ILEP's aim was to foster international education and development, cultivate leaders of change, and bridge geopolitical divides. The objectives were to provide educators with the opportunity to develop greater expertise in their educational roles, enhance their teaching skills, increase their knowledge about the USA, and develop an inquiry project focused on improving education in their local contexts upon their return. This was accomplished through an array of experiences including coursework on teaching methodologies and educational technologies, field experiences at local schools, and exposure to local civic and cultural 
activities. In this study, we examined one component of the ILEP program, a semester-long course centred on educational technology.

Our work adds to the limited body of research regarding teachers of developing nations and educational technologies, especially because ILEP participants represented many countries but also a collective group of developing nations. Most research on the technology-related education of teachers in international contexts has centred on teachers of developed countries such as Australia, Singapore, China, and the USA (Deng et al., 2017; Graham et al., 2012; Maor, 2016). Research on developing nations has primarily focused on the status of information and communication technology integration and related challenges (BuabengAndoh, 2012; Law et al., 2008). This research points to two needs regarding the adoption of educational technologies in developing nations: (a) providing technology access to teachers including computer labs and reliable Internet service and (b) providing meaningful technology education experiences to teachers. Teachers often act as agents of change in creating awareness about educational technologies (Dalal et al., 2017; Fisher, 2006). Moreover, researchers have affirmed the value of the 'train the trainer' or 'cultivate leadership' models for wide and sustaining impacts (Hofer et al., 2016). However, context-driven research examining the technology integration expertise of teachers from developing nations is limited (Voogt \& Plomp, 2010). The question remains: how can institutions of higher education play a critical role in developing teachers' knowledge, skills, and dispositions to facilitate effective integration of technology?

To explore this role and the many facets of teacher development specific to the effective integration of educational technology, a useful conceptual model is technological pedagogical content knowledge (TPACK) (Mishra \& Koehler, 2006). Few recent studies have emphasised the relevance of TPACK framework for preparing international teachers to use classroom technologies (Batoya et al., 2015; Byker, 2014). Batoya et al. recommended "an elaborate training including TPACK with ICT experts in [teachers'] subject area" (p. 6). Byker (2014) stated that the TPACK framework "could prove to be instructive and fruitful for preparing so many teachers to meet the challenge of using technology" (p. 35). Despite these recommendations, there is a lack of research focusing on TPACK development in developing countries (Hofer et al., 2016).

The current study aimed to address this by examining a semester-long intervention to facilitate TPACK among teachers from developing nations. The goal was to help advance the knowledge base of evidencebased practices in international technology integration programs and inform the future design of international teacher exchange programs in higher education. Recently, there has been increased attention towards technological readiness in developing nations. Governments are investing in technology infrastructure and providing policy support to widen the adoption of educational technologies (Baller et al., 2016; UNESCO, 2015). However, many in-service teachers lack competence in technology integration (Westbrook et al., 2013). If offered, professional development efforts have been sporadic, poorly resourced (Makgato, 2012), and focused on basic technologies such as word processing, spreadsheets, presentation software, or content-specific tools for science or mathematics (Karatas et al., 2017).

One key element is to support teachers with effective technology-related professional development that takes participants' views and backgrounds into account. Although access to technology can be a powerful factor guiding technology integration decisions, there are other influential elements, such as student engagement, desire to improve one's teaching practice, and an understanding of the benefits of technology for learning gains (Graham et al., 2012; Ottenbreit-Leftwich et al., 2018). This study explored how these factors aligned with the TPACK constructs across teachers from multiple developing nations. By aligning teachers' rationales with the constructs of the TPACK framework, we sought to provide a deeper understanding of the opportunities for designing context-relevant learning for international teachers from developing nations.

Using the TPACK framework, the study addressed the following research questions:

(1) What is the perceived ability of integrating technology in instruction for the international teachers from developing nations before and after a semester-long technology integration course at a host university?

(2) How do international teachers from developing nations approach technology integration in their instruction planning following their international exchange experience? 


\section{TPACK}

Since its inception, the TPACK framework has been used extensively to understand practices in technology education using either quantitative or qualitative approaches (Archambault, 2016; Chai et al., 2016). Most studies have relied on survey instruments to understand each of the seven TPACK domains (Karatas et al., 2017; Lee \& Tsai, 2010). These instruments have proved useful to assess outcomes of interventions, examine relationships among TPACK domains, and understand technology-related perceptions and efficacies of teachers. However, the survey measures have been less effective in explaining TPACK within contexts, thereby giving rise to qualitative measures (Archambault, 2016; Koh et al., 2010).

For example, using discourse analysis, Koehler et al. (2007) concluded that developing TPACK is a complicated process involving "deeper understandings of the complex web of relationships between content, pedagogy and technology and the contexts in which they function" (p. 758). Other qualitative measures such as observations and interviews have proven useful in understanding teacher reasoning and approaches to technology integration (Hofer et al., 2011; Jaipal \& Figg, 2010). Performance-based assessments such as lesson plans and design tasks have been used to examine the situated form of TPACK (Graham et al., 2012; Harris \& Hofer, 2011). Researchers have also used design measurement rubrics and content analysis to explain the influence of TPACK constructs on lesson design (Chai et al., 2016). In the last decade, many TPACK inquiries have also focused on TPACK-in-action to further understand how TPACK is developed in education courses (Harris \& Hofer, 2011; Koh et al., 2014; Paneru, 2018). These studies not only illustrated the interplay between TPACK and contextual factors but also demonstrated how contextual concerns can be turned into opportunities with appropriate design activities to support improvement.

Cumulatively, the literature suggests that TPACK is comprised of an intricate web of entwined relationships that is highly dependent on the context. A comprehensive review (Voogt et al., 2013) called for additional research to further understand teachers' technological reasoning and resulting instructional decisions. In addition, there has been a call for a greater focus on teachers' decision-making process when it comes to using technology in the classroom. Researchers have emphasised the importance of examining how teachers conceive of what is best for them and their students and the ways technology may play a role (Kopcha et al., 2020).

According to Chai et al. (2016), "A comprehensive picture of teachers' TPACK would require multiple assessments from both quantitative and qualitative perspectives" (p. 103). The current research builds upon a limited number of existing mixed-methods studies. The goal was to address larger issues around how to support developing nations in advancing technology infrastructures (UNESCO, 2015). Top-down changes from governments are one option, but bottom-up changes, such as those led by teachers, may also be valuable (Dalal, 2012). In this study, we explored if and how an international teacher exchange program designed specifically for teachers from developing countries may have supported teachers in teaching with and about technology. We aimed to illuminate the technology-related needs of teachers from developing nations, ultimately supporting the design of future teacher education of this nature.

\section{Methodology}

\section{Context}

The study took place at a public research university in the USA. We provided a semester-long education technology course that addressed technology literacy as well as practical technology tools for classroom instruction and planning. The course was designed to align to the International Society for Technology in Education Standards for Teachers (2014). It aimed to equip the international teachers with instructional technology resources and integration skills in a collaborative environment. Throughout the course, teachers explored technology through hands-on activities designed based on their backgrounds, comfort levels with technology, and technology interests, obtained via a welcome survey. Topics included learning theory and technology, digital citizenship, Internet safety, web-based communication, student and teacher productivity, assessment, and mobile learning. Coursework was divided into 10 three-hour in-person sessions held from mid-January to April in 2017. The course culminated with a design task to create a technology-infused lesson. The detailed course calendar is available at the Arizona State University's 
repository (2020a). The research team consisted of the lead instructor, an associate professor of education technology, who was assisted by two doctoral students. Human subjects research approval was sought from the internal review board of the university, and all 16 teachers agreed to participate.

\section{Participants}

Participants consisted of two teachers from each of the following nations: Bangladesh, Brazil, Ghana, India, Indonesia, Malaysia, Morocco, and Tanzania. All participants, consisting of an equal number of male and female teachers, had undergone ILEP's application process, which required at least 7 years of teaching experience in a secondary school, a bachelor's degree, English language proficiency, and a commitment to the teaching profession. The average age of participants was 38 years, ranging from 24 to 49 years. Teaching experience ranged from 6 to 21 years, with an average of 12 years. Participants reported a wide range of exposure and experience with computer technology (Table 1).

Table 1

Profile of participants

\begin{tabular}{lll}
\hline Professional and technology experience & Response count & Response \% \\
\hline Content area & 10 & 62 \\
$\quad$ Language Arts & 3 & 19 \\
Science & 3 & 19 \\
Social Studies & & \\
Started using technology & 0 & 0.0 \\
$\quad$ Prior to age 10 & 2 & 12 \\
Age 10 to 15 & 4 & 25 \\
Age 16 to 20 & 10 & 63 \\
Age after 20 & & \\
Exposure to computers & 3 & 19 \\
1 to 5 years & 5 & 31 \\
6 to 10 years & 4 & 25 \\
11 to 15 years & 3 & 19 \\
16 to 20 years & 1 & 6 \\
21 to 25 years & & \\
Time spent on computer in a typical work day & 0 & 0 \\
No time & 5 & 31 \\
Less than one hour & 4 & 25 \\
About 1-2 hours & 5 & 31 \\
About 3-4 hours & 2 & 13 \\
5 or more hours & & 0 \\
Comfort level using computer & 0 & 31 \\
Not at all comfortable & 5 & 44 \\
Somewhat comfortable & 7 & 25 \\
Comfortable & 4 &
\end{tabular}

\section{Procedures}

At the start of the course, all participants were given an overview of the TPACK framework emphasising that knowing how to use computer technology alone does not guarantee effective integration of technology (Mishra \& Koehler, 2006). Although the course was designed to address TK for those who were new technology users and who needed it, the primary focus was on building international teachers' TCK and TPK, which overlap to comprise TPACK as a whole. For example, we explored the topic of digital citizenship and how teachers can cover related concepts since this aligns with TPK to use technology to effectively communicate and facilitate appropriate interactions among students. To address TCK, we introduced teachers to online courseware to be able to deliver instruction and explored the use of technological representations (such as content-specific online video content and online science simulations available via PhET labs at http://phet.colorado.edu). To address TPACK-in-action, we employed a projectbased approach where the international teachers developed a lesson for their content area integrating 
technology-related resources. This design task provided an opportunity for the teachers to make decisions, plan technology integration in their own curricula, and engage in peer review. Throughout the course, participants completed a variety of hands-on individual and group assignments, such as creating an online slideshow, producing a digital story to teach a particular topic, and designing an online portfolio. These assignments served as an ongoing means to demonstrate the international teachers' understanding of the technology and its potential classroom application. An analysis of the design task offered insights about teachers' ability to conceptualise, design, and plan instruction infused with technology.

\section{Design and data sources}

Despite its theoretical value, the TPACK framework has been criticised for potential problems when used in practice due to the fuzziness of its domains (Archambault \& Barnett, 2010; Brantley-Dias \& Ertmer, 2013). Also, research has struggled to find evidence of convergent and discriminant validity when using multiple, independently validated measures suggesting additional problems with the framework as a whole (Kopcha et al., 2014). Despite the issues, researchers have agreed on the usefulness of the framework for examining technology integration (Kopcha et al., 2014). Consequently, we chose a concurrent mixedmethods design that allowed for multiple lenses in the same inquiry space (Greene, 2007). We collected quantitative data via a TPACK survey and qualitative data via a design task. By collecting multiple forms of data, we compensated for the limitations of each method and through triangulation were able to create a more coherent understanding of the questions under study (Greene, 2007).

\section{Survey}

To answer the first research question regarding participants' perceived technology integration abilities, we utilised a survey adapted from a validated TPACK measure (Archambault \& Crippen, 2009). We modified the instrument, originally designed for online instruction, to make it relevant for face-to-face class instruction and current educational technologies. The survey questions asked participants to rate their ability to conduct various instructional activities on a 5-point Likert-scale (not at all able, rarely able, sometimes able, often able, and most of the time able) across 24 items. The lead instructor administered the survey, once before the course began and again at its conclusion.

\section{Design task}

In the last 2 weeks of the course, participants designed a lesson plan incorporating at least one educational technology tool. They also included rationales for their design decisions, describing why they chose a particular technology, how the technology enhanced the instruction, and how the technology would be used by the teacher and/or students. The design task guidelines are available at the Arizona State University's repository (2020b). The design task explained how TPACK was put into action and what contextual elements affect the design of technology-infused lessons.

\section{Analysis}

\section{Survey}

We evaluated the survey items measuring the 16 participants' perceptions of their abilities to integrate educational technologies both before and after the course. The Likert-scale items were assigned values as follows: not at all able (1), rarely able (2), sometimes able (3), often able (4), and most of the time able (5). The research team calculated descriptive statistics for the seven TPACK constructs and established internal reliability by verifying Cronbach's alpha.

\section{Design task}

We identified 94 statements for qualitative analysis as data units across the 16 sets of submitted materials. Data units were ideas that pertained to either a specific educational technology, a justification for choosing that technology, or its intended use. Together, two members of the research team read and re-read the data units, first coding for the presence of one of the four technology-related TPACK domains (TK, TPK, TCK, or TPACK). Next, we used open coding (Corbin \& Strauss, 2015) on the same data units to identify additional unpredicted themes. We consolidated or expanded codes as necessary until coding saturation was reached, and a coding scheme was agreed upon by all members of the research team. Then, one researcher coded the remaining data units. The lead researcher checked the inter-rater reliability using the percentage of agreement, which was found to be $78 \%$. By convention, a value of $70 \%$ and above is considered as an acceptable inter-rater reliability for social sciences research (Armstrong et al., 1997; 
Kalajahi \& Abdullah, 2015). The research team met again to resolve any discrepancies and to come to a full agreement.

The decision to use both inductive and deductive coding followed Graham et al.'s (2012) dual coding approach. One reason for using dual coding was that the fuzziness of the TPACK domains make it difficult to separate out each of the domains (Archambault \& Barnett, 2010). Second, we wanted to look for evidence that was not specifically addressed in the TPACK domains but was relevant to teachers' technology-infused lesson planning process. The open codes aligned to TPACK constructs provided a better understanding of how or why the international teachers would or would not integrate technology into their lesson designs. This type of analysis was particularly helpful because it "provides insight for researchers attempting to make such distinctions" when details for differentiating between and among TPACK domains are lacking (Graham et al., 2012, p. 542). The combined codes explained how international teachers went about making decisions. The results, discussed in the following section, revealed what was working well and what needed to be improved within the course.

\section{Results}

\section{Survey: Perceived ability of technology integration}

Table 2 displays aggregated descriptive statistics for all the TPACK domains. International teachers began the course with greater levels of reported abilities pertaining to CK $(M=3.73)$, PK $(M=3.37)$, and PCK $(M=3.12)$. Knowledge levels were lower in all technology-related constructs. After completing the course, participants' confidence levels for technology-related constructs advanced to match other non-technologyrelated construct values with higher growths observed in the domains of TCK, TPACK, and TPK.

Table 2

Descriptive statistics for TPACK constructs and reliability scores

\begin{tabular}{lcccccc}
\hline & \multicolumn{2}{c}{ Pre-survey results } & \multicolumn{2}{c}{ Post-survey results } & Gain & Cronbach's alpha \\
\hline Construct & $M$ & $S D$ & $M$ & $S D$ & $M$ & \\
TK & 2.60 & 0.87 & 3.75 & 0.94 & 1.15 & .691 \\
PK & 3.37 & 1.13 & 4.62 & 0.67 & 1.25 & .751 \\
CK & 3.73 & 1.01 & 4.49 & 0.68 & 0.76 & .627 \\
TPK & 2.92 & 1.11 & 4.49 & 0.63 & 1.57 & .788 \\
PCK & 3.12 & 1.16 & 4.37 & 0.75 & 1.25 & .763 \\
TCK & 2.52 & 1.13 & 4.36 & 0.72 & 1.84 & .817 \\
TPACK & 2.65 & 1.09 & 4.36 & 0.80 & 1.71 & .821 \\
\hline
\end{tabular}

Note. $M=$ mean, $S D=$ standard deviation. Means and standard deviations computed from responses $(N=16)$ on the following scale: not at all able (1), rarely able (2), sometimes able (3), often able (4), and most of the time able (5).

\section{Design task: Technology integration in instructional planning}

Results reveal that the largest portion (40\%) of the data units were related to TPK followed by TK (18\%), TPACK (15\%), and TCK (8\%) (Table 3). The remaining 19\% data units simply mentioned specific technologies that international teachers were planning to use in instruction. These included statements such as, "I will use this Khan Academy video to teach basic statistics." Specific technologies mentioned included Kahoot, Voice Thread, YouTube, Prezi, PowerPoint, Moviemaker, PhotoPeach, Screencast-O-Matic, Google Forms, Audiobook, Poll Everywhere, and the Illuminations website from National Council of Teachers of Mathematics.

Table 3

Breakdown of codes for design task rationales

\begin{tabular}{lc}
\hline Code & \% evidence \\
\hline TPK & 40 \\
TK & 18 \\
TPACK & 15 \\
TCK & 8 \\
Specific technologies & 19 \\
\hline Note. Percentages calculated from $N=94$ rationale statements.
\end{tabular}


Table 4 presents a codebook of teachers' rationales for technology integration.

Table 4

Codebook with examples

\begin{tabular}{|c|c|c|c|}
\hline Code & Description & $\begin{array}{l}\% \\
\text { evidence }\end{array}$ & Example \\
\hline $\begin{array}{l}\text { TK.af } \\
\text { (affordance) }\end{array}$ & $\begin{array}{l}\text { Teacher describing what the } \\
\text { technology adds considering } \\
\text { the benefits or advantages of } \\
\text { technology in education. }\end{array}$ & 11 & $\begin{array}{l}\text { "Google Forms allows you to ask both } \\
\text { open-ended and closed-ended } \\
\text { questions." }\end{array}$ \\
\hline $\begin{array}{l}\text { TK.rc } \\
\text { (resource } \\
\text { constraints) }\end{array}$ & $\begin{array}{l}\text { Teacher thinking about } \\
\text { available technology resources } \\
\text { and school policy constraints. }\end{array}$ & 5 & $\begin{array}{l}\text { "I chose Powerpoint and Youtube } \\
\text { because these are the only resources } \\
\text { that can be used in my school." }\end{array}$ \\
\hline $\begin{array}{l}\text { TPK.is } \\
\text { (instructional } \\
\text { strategy) }\end{array}$ & $\begin{array}{l}\text { Use of technology for a } \\
\text { specific instructional strategy } \\
\text { or a particular pedagogical } \\
\text { goal such as assessment. }\end{array}$ & 21 & $\begin{array}{l}\text { "After viewing a YouTube video, } \\
\text { encourage online discussion by asking } \\
\text { learners to add their personal insights: } \\
\text { What did they like about the video? } \\
\text { Was there anything they didn't } \\
\text { understand? How did the video relate } \\
\text { to their personal } \\
\text { experiences/feelings?" }\end{array}$ \\
\hline $\begin{array}{l}\text { TPK.af } \\
\text { (affordance) }\end{array}$ & $\begin{array}{l}\text { An instructional strategy that } \\
\text { involves use of technology } \\
\text { specifically considering the } \\
\text { affordance of the particular } \\
\text { technology tool. }\end{array}$ & 7.5 & $\begin{array}{l}\text { "Using YouTube videos in lesson } \\
\text { encourages your audience to develop } \\
\text { their note-taking skills by viewing, } \\
\text { rewinding, and replaying the video } \\
\text { until they have fully grasped its } \\
\text { essence and key points." }\end{array}$ \\
\hline $\begin{array}{l}\text { TPK.lu } \\
\text { (learner } \\
\text { understanding) }\end{array}$ & $\begin{array}{l}\text { An instructional strategy that } \\
\text { involves use of technology but } \\
\text { keeping in mind the } \\
\text { background, abilities, and } \\
\text { motivations of the learner. }\end{array}$ & 7.5 & $\begin{array}{l}\text { "As a teacher of classes with inclusion } \\
\text { students and at risk students, I have } \\
\text { found that measurable differences } \\
\text { occur in learning and retention } \\
\text {...Algebra tiles website can assist } \\
\text { their learning process from concrete to } \\
\text { symbolic." }\end{array}$ \\
\hline $\begin{array}{l}\text { TCK.af } \\
\text { (affordance) }\end{array}$ & $\begin{array}{l}\text { Teacher talking about a } \\
\text { particular technology tool } \\
\text { considering its affordance and } \\
\text { relevance for specific content. }\end{array}$ & 3 & $\begin{array}{l}\text { "Chemistry experiments are } \\
\text { hazardous, one cannot see what's } \\
\text { happening at molecular level. PhET } \\
\text { allows to see and conduct experiments } \\
\text { again and again if something goes } \\
\text { wrong." }\end{array}$ \\
\hline $\begin{array}{l}\text { TCK.rc } \\
\text { (resource } \\
\text { constraints) }\end{array}$ & $\begin{array}{l}\text { Considering a technology tool } \\
\text { for its relevance to specific } \\
\text { content while weighing the } \\
\text { technology access issues and } \\
\text { resource constraints. }\end{array}$ & 2.5 & $\begin{array}{l}\text { "Show google earth as it is useful for } \\
\text { geography lesson. No internet in } \\
\text { school but has personal connection } \\
\text { through mobile. The plan to show } \\
\text { google earth may fail." }\end{array}$ \\
\hline $\begin{array}{l}\text { TCK.tp } \\
\text { (teacher } \\
\text { planning) }\end{array}$ & $\begin{array}{l}\text { Teacher planning the lesson } \\
\text { thinking about content and } \\
\text { technology. }\end{array}$ & 2.5 & $\begin{array}{l}\text { "Power point will be used in early } \\
\text { stage, (New knowledge presentation) } \\
\text { to explain the content of the lesson." }\end{array}$ \\
\hline
\end{tabular}




\begin{tabular}{|c|c|c|c|}
\hline $\begin{array}{l}\text { TPACK.is } \\
\text { (instructional } \\
\text { strategy) }\end{array}$ & $\begin{array}{l}\text { Teacher combining pedagogy, } \\
\text { content, and technology in } \\
\text { instructional strategy however, } \\
\text { one domain may be prevalent. }\end{array}$ & 9 & $\begin{array}{l}\text { "Students will watch the video about } \\
\text { exploring the coral reef. Students will } \\
\text { discuss and pose questions about the } \\
\text { video they have watched." }\end{array}$ \\
\hline $\begin{array}{l}\text { TPACK.af } \\
\text { (affordance) }\end{array}$ & $\begin{array}{l}\text { An instructional strategy for a } \\
\text { particular content that involves } \\
\text { meaningful use of technology } \\
\text { considering the affordance of } \\
\text { the particular technology." }\end{array}$ & 2 & $\begin{array}{l}\text { "Stop the video at } 4: 59 \text { minutes and } \\
\text { solve the following sums from your } \\
\text { textbook based on arithmetic mean. } \\
\text { You may watch the video again for } \\
\text { clarity and understanding." }\end{array}$ \\
\hline $\begin{array}{l}\text { TPACK.lu } \\
\text { (learner } \\
\text { understanding) }\end{array}$ & $\begin{array}{l}\text { Teacher talking about an } \\
\text { instructional strategy for a } \\
\text { particular content that involves } \\
\text { use of technology but keeping } \\
\text { in mind the background and } \\
\text { abilities of the learner. }\end{array}$ & 2 & $\begin{array}{l}\text { "Students often have difficulty } \\
\text { learning Mathematics especially } \\
\text { algebra. It is deemed too abstract and } \\
\text { students cannot represent the numbers } \\
\text { and variables physically. But students } \\
\text { can understand algebraic thinking and } \\
\text { its concepts with Algebra tiles website } \\
\text { that takes geometric approach to } \\
\text { algebraic concepts." }\end{array}$ \\
\hline
\end{tabular}

Note. Percentages calculated based on $N=94$ rationale statements.

\section{Design task: Teachers' instructional planning decisions}

Next, we describe the qualitative results for each of the four technology-related TPACK constructs and explain the nature of teachers' instructional planning decisions.

$T K$

TK represents the knowledge necessary to understand and use technologies. We expected to find low number of TK rationales given comparatively lower gain in TK on the survey results. However, $11 \%$ of rationales indicated teachers' understanding of the affordance of technology (coded as TK.af) as evidenced from the following participant statement: "Technology will be a tool for the students to have effective learning on the text and to reflect on what it can relate to their lives."

Teachers also indicated constraints in using technology despite understanding the use of technology. A teacher from Malaysia wrote, "This lesson unit is attempt to utilize the internet capacity and computer lab available in the school because students do not have equal access to technological resources at home." Resource constraints (coded as TK.rc) comprised 5\% of the data units. Overall, the statements related to TK indicated teachers' understanding of and desire to use technology.

$T P K$

TPK represents teachers' knowledge of how to integrate technology with teaching approaches. The largest portion of teacher rationales $(40 \%)$ represented TPK. These were further broken down into use of technology for a specific instructional strategy (TPK.is), use of technology considering its affordance for a specific instructional purpose (TPK.af), and use of technology for instruction while understanding the abilities of the learners (TPK.lu). The most frequent rationale was for a specific instructional strategy, comprising $21 \%$ of the data units. An example of how teachers used technology for a specific learning activity was evident in one participant's 5-day unit for his secondary-level English class. He wrote:

On the first day, teacher shows a slide presentation of the project for the week and the required text: The Black Cat, from Edgar Allan Poe. At the end of the presentation, students are invited to clarify their doubts [...] On the second day, teacher brings audiobook. The text is read (or listened) during the class period [...] In the last day, students get engaged in a Kahoot activity, with questions about the text read for assessment.

Throughout the unit plan, this teacher demonstrated an ability to use various technologies to achieve pedagogical goals including content presentation, practice, and assessment. 
Another TPK rationale involved leveraging the affordances of technology $(7.5 \%)$. Teachers were considering benefits of technology in education such as motivation and engagement for students, clarification of complex concepts, or ease of collaboration. For example, a science teacher wrote, "YouTube videos allow you to better illustrate complex concepts, procedures, and ideas."

The final TPK rationale was that technology was used for instruction considering the abilities of the learners (7.5\%). Teachers had knowledge of their students' technological abilities and preferences, so they were thinking about what technologies their students will be able to use easily. For example, a teacher stated:

Students will learn by making power point show, movie maker and PhotoPeach. The students in my school is not advance in the use of technology. Not only they have struggle in understanding the English language itself but to burden them with complicated instruction of new application or unfamiliar tools is irrelevant.

Overall, the TPK rationales represented the strongest domain among participants.

$T C K$

TCK represents teachers' knowledge of technology tools within a content discipline. With the highest growth reported in TCK on the survey, we expected a higher number of rationales specific to TCK. However, participants' design task showed very little evidence of TCK ( $8 \%$ of data units). Upon reflection, considering that the course was not designed to be content-specific given the wide array of teaching backgrounds and assignments of the participants, this could have been expected. In addition, the lack of consistency among TPACK measures has been well documented (Kopcha et al., 2014).

One factor that seemed to influence teachers' reasoning related to TCK was resource constraints. These statements were coded as TCK.rc. For example, one social studies teacher wrote in her lesson plan that she would have liked to use Google Maps in her classroom but since there is no Internet in her school, she would have to rely on paper maps and charts. The theme of technology affordance was once again evident in TCK rationales. For instance, one Brazilian teacher planned to use VoiceThread to teach English diction to his students. Additionally, $2.5 \%$ of statements aligned to the theme of planning (coded as TCK.tp) to teach particular content. As an example, one teacher had "compiled articles and videos" on a specific topic with plans to use them upon return to his classroom. Overall, TCK rationales were the least coded category among TPACK domains.

\section{TPACK}

TPACK represents teachers' understanding of the complexity of relationships among students, teachers, content, technologies, and practices. Themes were organised into three TPACK categories: general instructional strategies combining content, technology, and pedagogy (TPACK.is); knowledge of technology affordance for meaningful content teaching (TPACK.af); and knowledge of learner for meaningful teaching (TPACK.lu). TPACK rationales on general instructional strategies represented $9 \%$ of data units and were reflected in statements such as, "Students will create a digital presentation about any threatened marine species as part of the effort to identify marine diversity locally or any parts of the world." Of the data units, $2 \%$ indicated meaningful use of technology in lesson planning with an understanding of the affordance of technology. For example, one teacher wanted students to "stop the video at 4.59 minutes," go back to the textbook to solve a particular problem, and then resume video viewing. Another $2 \%$ of the rationales focused on teachers' understanding of the learners as they chose technologies that were "easier tools for the students to use." Overall, TPACK rationales indicated that teachers were thinking about students' involvement in the use of technology to make learning meaningful.

\section{Discussion and implications}

This study aimed to explore the development of TPACK among international teachers from developing nations who participated in one cohort of the U.S. Department of State's cultural exchange program, ILEP. As world governments invest in improving technology infrastructure in developing nations (UNESCO, 2015), teachers in these countries will play an important role in supporting future generations of students to leverage the new technology infrastructures. We see ILEP's efforts in teacher education as one answer to the challenge of technology adoption in developing nations. The present study began to explore the 
impact of the approach, examining a single component of the ILEP experience - the technology course among participants at one host university.

Survey results indicated that after participating in the course, participants showed growth in all technologyrelated constructs. This suggests that the exchange program was an effective approach to improving teachers' confidence around educational technology. This growth occurred across participants who represented a variety of developing nations, who taught different subjects and grade levels, and who possessed varying levels of technological experience. Gains in TPACK may have occurred because throughout the course, teachers developed new technology knowledge and skills around topics such as video production, mobile technology, and screencasting. These hands-on (active learning) experiences were then coupled with class discussion about how to use these technologies with students, along with the other components of the ILEP program such as classroom observations at local secondary schools and other university course work. The synthesis of these experiences may have helped participants develop their understanding of the educational affordances in given technologies, improving TPACK.

The design task analysis also indicated greater presence of TPK compared to TK, TCK, or TPACK. The ILEP participants were highly experienced teachers, so it was not surprising that their confidence in pedagogical knowledge would be relatively high. This finding highlights the fact that the technology course seemed to have leveraged teachers' existing pedagogical skills effectively, to impart new technological knowledge, which may not be as effective for teachers with less teaching experience. As Niess (2005) suggested, building a strong foundation of PCK is key for developing TPACK.

Another important finding was that in teachers' lesson designs, they considered learner background, affordance of technology, instructional strategies, and access issues. The theme of affordance was documented within all technology-related constructs (TK.af, TPK.af, TCK.af, and TPACK.af). The knowledge of a tool's affordance is suggestive of advanced thinking about how technology can enhance content and pedagogy (Koehler et al., 2012). The international teachers in this study considered the benefits of technology in various ways and at different stages of instructional planning. They thought about how the teaching and learning process could be enhanced with technology, rather than simply using the technology for the sake of doing so. In addition, TPK was a clear strength among the international teachers. While designing lessons, teachers were thinking about pedagogy - how they were going to teach a particular topic, what difficulties their students might face, and how they were going to assess the learning, and where technology might play a meaningful role. This aligns with the understanding that teachers do not inherently consider technology skills alone or separate out domains of content, pedagogy, and technology when planning; teachers consider these elements together (Archambault \& Barnett, 2010). It should also be noted that gains in TPACK may have been more pronounced and evident had the international teachers had the opportunity to enact their design tasks in their own classrooms; however, this was not possible during the course since it was part of the exchange program offered while they were in the USA.

Triangulating the survey results with the design task results, it seemed that while teachers felt confident in integrating technology across their content areas, their ability to apply their confidence to the lesson design process was limited. One reason could be access issues. Six teachers indicated a lack of Internet connection or computers in their school. Teachers also indicated that students' access to computers and the Internet at home was limited. These technology limitations may act as gatekeepers, constraining teachers from designing lessons suggestive of TCK or TPACK, where technology is used constructively with the full involvement of students (Mishra \& Koehler, 2006). Another reason could be that learning activities in the technology course were typically not tailored to specific content areas because participants' content areas, grade levels, and prior experiences with technology varied widely. Previous studies have also acknowledged that exposing participants to more content-specific technology integration examples is a challenge (Graham et al., 2012; Harris \& Hofer, 2011). An added issue is that educational technologies may rarely be designed with specific content objectives in mind (Forssell, 2016; Laurillard, 2009). Therein lies an opportunity for designers to leverage teacher knowledge and create content-specific technology tools, particularly those that support different languages and can be used off-line.

In summary, the international teachers began their exchange experience with limited confidence in their ability to integrate technology in the classroom. During the semester, they explored new educational technologies, built upon their integration skills, and learned to think about the affordances of these technologies in connection with their instructional strategies, thus contributing to their understanding of 
TPACK-in-action (Harris \& Hofer, 2011). Through additional activities in the program, such as observing in local high schools and taking university level courses of their choosing, they had further varied experiences with educational technology. They worked collaboratively with other teachers from around the world as well as with teachers and faculty from the local USA high schools and university. Participants also benefitted by taking part in this research inquiry, which provided them with an opportunity to reflect on their practices and learnings, and we promised to share the published results.

By building the technology integration capacity of international teacher leaders, the impact may be farreaching. One of the goals of the program was to select exemplary teachers who were committed to their craft, so that they might hone their skills and share their learning with fellow teachers in their home countries. From our email interactions with ILEP participants after their return, we know that ILEP experiences have sparked motivation to create different learning environments back home. For example, a teacher from Kenya downloaded a multitude of videos and bought a projector while she was in the USA, painted the classroom walls white upon return, and now uses her laptop and projector to show videos to her science students (Dalal \& Archambault, 2018). A teacher from India was able to expand technology in his school by working with administrators, parents, and non-profit organisations. The school was recognised as one of the model "changemaker schools" (Ashoka, 2018). Consequently, we see tremendous value in cultural exchange models such as ILEP.

\section{Limitations and future research}

A limitation of this study is that it used self-report survey measures, which are susceptible to bias (Fowler, 2002). The single group, pre-post design with a small number of participants has inherent limitations. However, we worked to minimise these concerns by adapting a previously validated instrument and implementing a mixed methods approach to triangulate findings. By including the design task, we were able to draw interpretations based on the combined methodological strengths of both datasets (Creswell, 2014). We also used both inductive and deductive qualitative coding to further overcome the fuzziness of TPACK domains in interpretations (Brantley-Dias \& Ertmer, 2013). That said, the extent to which the findings are generalisable is limited; however, considering that research on the topic of international teacher development with respect to technology integration is narrow, particularly for teachers of developing nations, this study makes a useful contribution.

Future research includes a longitudinal study with past ILEP participants to examine their actual classroom practices. Studies with a different design task would also help describe international teachers' technology integration approaches more completely, along with following the actual implementation of their design tasks. Another area for future exploration is to focus more squarely on international teachers' decisionmaking process when it comes to using technology in the classroom using the teacher response model described by Kopcha et al. (2020). In addition, studies with additional participants, perhaps at the other ILEP host universities, would provide evidence on a larger scale.

\section{Conclusion}

The current study contributes to the growing body of research about technology integration in the teacher education community. More importantly, the study expands the current quest to a global level by understanding technology integration decisions among teachers who participated in the ILEP, an exchange program designed for teachers of developing nations. With governments investing in and working to improve technology infrastructure (UNESCO, 2015), preparing teachers for meaningful technology integration becomes essential in developing nations. Successful education reform is a combination of topdown and bottom-up change (Dalal, 2012). Teachers may help bring the grassroots level change necessary in the bigger picture of reform (Dalal et al., 2017; Fisher, 2006). International collaborations and teacher exchange programs such as ILEP may be effective vehicles for international teachers to engage in meaningful learning and to disseminate the knowledge back home. Lawless and Pellegrino (2007) emphasised that the digital divide between urban and rural schools in the USA is not because of a lack of access to technology, but rather, due to the lack of access to teachers who are able to integrate classroom technology effectively. This discovery has even larger implications in the context of developing nations, 
where there is a critical and continuing shortage of teachers and trainers equipped to integrate technology in education (Buabeng-Andoh, 2012). Our hope is that the current study will provide added focus on the technology-related needs of teachers from developing nations, and at the same time, contribute towards the context driven future design of international teacher education programs.

\section{References}

Archambault, L. (2016). Exploring the use of qualitative methods to examine TPACK. In M. C. Herring, M. J. Koehler, \& P. Mishra (Eds.), Handbook of technological pedagogical content knowledge (TPACK) for educators (pp. 75-96). Routledge.

Archambault, L., \& Barnett, J. H. (2010). Revisiting technological pedagogical content knowledge: Exploring the TPACK framework. Computers \& Education, 55(4), 1656-1662. https://doi.org/10.1016/j.compedu.2010.07.009

Archambault, L., \& Crippen, K. (2009). Examining TPACK among K-12 online distance educators in the United States. Contemporary Issues in Technology and Teacher Education, 9(1), 71-88. https://citejournal.org/volume-9/issue-1-09/general/examining-tpack-among-k-12-online-distanceeducators-in-the-united-states/

Arizona State University. (2020a). ILEP Technology course calendar. https://repository.asu.edu/attachments/227659/content/Course\%20Calendar.pdf

Arizona State University. (2020b). ILEP Course - Design task guidelines. https://repository.asu.edu/attachments/227660/content/Design\%20Task.pdf

Ashoka. (2018). Ashoka changemaker schools. https://www.ashoka.org/en-in/program/ashokachangemaker-schools

Armstrong, D., Gosling, A., Weinman, J., \& Marteau, T. (1997). The place of inter-rater reliability in qualitative research: An empirical study. Sociology, 31(3), 597-606. https://doi.org/10.1177\%2F0038038597031003015

Baller, S., Dutta, S., \& Lanvin, B. (Eds.). (2016). The Global information technology report 2016. World Economic Forum. http://www3.weforum.org/docs/GITR2016/WEF GITR Full Report.pdf

Batoya, I. B., Wabwoba, F., \& Kilwake, J. (2015). Influence of social technical factors on ICT readiness for primary schools in Bungoma County, Kenya. Unified Journal of Computer Science Research, $1(1), 1-7$. http://erepository.kibu.ac.ke/handle/123456789/1090

Brantley-Dias, L., \& Ertmer, P. A. (2013). Goldilocks and TPACK: Is the construct 'just right?' Journal of Research on Technology in Education, 46(2), 103-128. https://doi.org/10.1080/15391523.2013.10782615

Buabeng-Andoh, C. (2012). Factors influencing teachers' adoption and integration of information and communication technology into teaching: A review of the literature. International Journal of Education and Development using Information and Communication Technology, 8(1), 136-155. https://www.learntechlib.org/p/188018/

Byker, E. (2014). ICT in India's elementary schools: The vision and realities. International Education Journal: Comparative Perspectives, 13(2), 27-40. https://openjournals.library.sydney.edu.au/index.php/IEJ/article/viewFile/6880/8433

Chai, C. S., Koh, J. H. L., \& Tsai, C. C. (2016). A review of the quantitative measures of technological pedagogical content knowledge (TPACK). In M. Herring, M. Koehler, \& P. Mishra (Eds.), Handbook of technological pedagogical content knowledge (TPACK) for educators (pp. 87-106). Routledge.

Corbin, J., \& Strauss, A. (2015). Basics of qualitative research (4th ed.). Sage.

Creswell, J. W. (2014). A concise introduction to mixed methods research. Sage.

Dalal, M. (2012). Higher education and global challenges: An Indian perspective. International Journal of Social Sciences and Interdisciplinary Research, 1(5) 73-76. http://www.indianresearchjournals.com/pdf/IJSSIR/2012/May/10 IJS MAY2012.pdf

Dalal, M. \& Archambault, L. (2018). International teachers' evolving relationships with educational technology. In L. Liu \& D. Gibson (Eds.), Research highlights in technology and teacher education (pp. 135-143). Association for the Advancement of Computing in Education.

Dalal, M., Archambault, L., \& Shelton, C. (2017). Professional development for international teachers: Examining TPACK and technology integration decision making. Journal of Research on Technology in Education, 49(3-4), 117-133. https://doi.org/10.1080/15391523.2017.1314780 
Deng, F., Chai, C. S., So, H. J., Qian, Y., \& Chen, L. (2017). Examining the validity of the technological pedagogical content knowledge (TPACK) framework for preservice chemistry teachers. Australasian Journal of Educational Technology, 33(3), 1-14. https://doi.org/10.14742/ajet.3508

Fisher, T. (2006). Educational transformation: Is it, like "beauty", in the eye of the beholder, or will we know it when we see it? Education and Information Technologies, 11(3-4), 293-303. http://doi.org/10.1007/s10639-006-9009-1

Forssell, K. (2016). Making meaningful advances. In M. C. Herring, M. J. Koehler, \& P. Mishra (Eds.), Handbook of technological pedagogical content knowledge (TPACK) for educators (pp. 247-257). Routledge.

Fowler, F. J. (2002). Survey research methods (3rd ed). Sage.

Graham, C. R., Borup, J., \& Smith, N. B. (2012). Using TPACK as a framework to understand teacher candidates' technology integration decisions. Journal of Computer Assisted Learning, 28(6), 530-546. http://doi.org/10.1111/j.1365-2729.2011.00472.x

Greene, J. C. (2007). Mixed methods in social inquiry. Jossey-Bass.

Harris, J. B., \& Hofer, M. J. (2011). Technological pedagogical content knowledge in action: A descriptive study of secondary teachers' curriculum-based, technology-related instructional planning. Journal of Research on Technology in Education, 43(4), 211-229. https://doi.org/10.1080/15391523.2011.10782570

Hofer, M., Grandgenett, N., Harris, J., \& Swan, K. (2011). Testing a TPACK-based technology integration observation instrument. In M. Koehler \& P. Mishra (Eds.), Proceedings of the Society for Information Technology \& Teacher Education International Conference 2011 (pp. 4352-4359). Association for the Advancement of Computing in Education. https://www.learntechlib.org/primary/p/37015/.

Hofer, M., Lee, J. K., Slykhuis, D. A., \& Ptaszynski, J. (2016). Opportunities and challenges of TPACKbased professional development on a global scale. In M. Herring, M. Koehler \& P. Mishra (Eds.), Handbook of technological pedagogical content knowledge (TPACK) for educators (pp. 225-234). Routledge.

Howe, E. R., \& Xu, S. (2013). Transcultural teacher development within the dialectic of the global and local: Bridging gaps between East and West. Teaching and Teacher Education, 36, 33-43. http://doi.org/10.1016/j.tate.2013.06.010

International Research \& Exchanges Board. (2020). Fulbright distinguished awards in teaching program for international teachers (Fulbright DAI). https://www.irex.org/project/fulbright-distinguishedawards-teaching-program-international-teachers-fulbright-dai

International Society for Technology in Education. (2014). ISTE standards for teachers. https://www.iste.org/docs/pdfs/20-14_ISTE_Standards-T_PDF.pdf

Jaipal, K., \& Figg, C. (2010). Unpacking the "Total PACKage": Emergent TPACK characteristics from a study of preservice teachers teaching with technology. Journal of Technology and Teacher Education, 18(3), 415-441. https://www.learntechlib.org/primary/p/28335/

Kalajahi, S. A. R., \& Abdullah, A. N. (2015). Discourse connectors and cohesion in writing. Mediterranean Journal of Social Sciences, 6(3 S2), 441-447. https://doi.org/10.5901/mjss.2015.v6n3s2p441

Karatas, I., Tunc, M.P., Yilmaz, N., \& Karaci, G. (2017). An investigation of technological pedagogical content knowledge, self-confidence, and perception of pre-service mathematics teachers towards instructional technologies. Educational Technology \& Society, 20(3), 122-132. http://www.ifets.info/journals/20 3/10.pdf

Koehler, M. J., Mishra, P., \& Yahya, K. (2007). Tracing the development of teacher knowledge in a design seminar: Integrating content, pedagogy and technology. Computers \& Education, 49(3), 740762. https://doi.org/10.1016/j.compedu.2005.11.012

Koehler, M. J., Shin, T. S., \& Mishra, P. (2012). How do we measure TPACK? Let me count the ways. In R. N. Ronau, C. R. Rakes, \& M. L. Niess (Eds.), Educational technology, teacher knowledge, and classroom impact: A research handbook on frameworks and approaches (pp. 16-31). IGI Global.

Koh, J. H. L., Chai, C. S., \& Tay, L. Y. (2014). TPACK-in-Action: Unpacking the contextual influences of teachers' construction of technological pedagogical content knowledge (TPACK). Computers \& Education, 78, 20-29. https://doi.org/10.1016/j.compedu.2014.04.022

Koh, J. H. L., Chai, C. S., \& Tsai, C. C. (2010). Examining the technological pedagogical content knowledge of Singapore pre-service teachers with a large-scale survey. Journal of Computer Assisted Learning, 26(6), 563-573. https://doi.org/10.1111/j.1365-2729.2010.00372.x 
Kopcha, T. J., Neumann, K. L., Ottenbreit-Leftwich, A., \& Pitman, E. (2020). Process over product: the next evolution of our quest for technology integration. Educational Technology Research and Development, 1-21. https://doi.org/10.1007/s11423-020-09735-y

Kopcha, T. J., Ottenbreit-Leftwich, A., Jung, J., \& Baser, D. (2014). Examining the TPACK framework through the convergent and discriminant validity of two measures. Computers \& Education, 78, 8796. https://doi.org/10.1016/j.compedu.2014.05.003

Laurillard, D. (2009). The pedagogical challenges to collaborative technologies. International Journal of Computer-Supported Collaborative Learning, 4(1), 5-20. https://doi.org/10.1007/s11412-008-9056-2

Law, N., Pelgrum, W. J., \& Plomp, T. (Eds.). (2008). Pedagogy and ICT use in schools around the world: Findings the IEA SITES 2006 Study. Springer.

Lawless, K. A., \& Pellegrino, J. W. (2007). Professional development in integrating technology into teaching and learning: Knowns, unknowns, and ways to pursue better questions and answers. Review of Educational Research, 77(4), 575-614. https://doi.org/10.3102/0034654307309921

Lee, M. H., \& Tsai, C. C. (2010). Exploring teachers' perceived self-efficacy and technological pedagogical content knowledge with respect to educational use of the World Wide Web. Instructional Science, 38(1), 1-21. http://doi.org/10.1007/s11251-008-9075-4

Makgato, M. (2012). Identifying constructivist methodologies and pedagogic content knowledge in the teaching and learning of technology. Procedia-Social and Behavioral Sciences, 47, 1398-1402. https://doi.org/10.1016/j.sbspro.2012.06.832

Maor, D. (2016). Using TPACK to develop digital pedagogues: A higher education experience. Journal of Computers in Education. Advance online publication. https://doi.org/10.1007/s40692-016-0055-4

McConnell, D. (2000). Importing diversity: Inside Japan's JET program. University of California Press.

Mishra, P. \& Koehler, M. J. (2006). Technological pedagogical content knowledge: A framework for teacher knowledge. Teachers College Record, 108(6), 1017-1054. https://www.learntechlib.org/p/99246/

Niess, M. L. (2005). Preparing teachers to teach science and mathematics with technology: Developing a technology pedagogical content knowledge. Teaching and Teacher Education, 21(5), 509-523. https://doi.org/10.1016/j.tate.2005.03.006

Ottenbreit-Leftwich, A. T., Glazewski, K. D., Brush, T. A., Aslan, S., \& Zachmeier, A. (2018). Addressing technology integration concerns: Asynchronous video mentoring between pre-service teachers and exemplary technology-using in-service teachers. Australasian Journal of Educational Technology, 34(4). https://doi.org/10.14742/ajet.3246

Paneru, D. R. (2018). Information communication technologies in teaching English as a foreign language: Analysing EFL teachers' TPACK in Czech elementary schools. Center for Educational Policy Studies Journal, 8(3), 141-163. https://doi.org/10.26529/cepsj.499

UNESCO. (2015). The state of broadband 2015: Broadband as a foundation for sustainable development (A Report by the Broadband Commission for Digital Development). ITU \& UNESCO. https://core.ac.uk/reader/30671076

Voogt, J., Fisser, P., Pareja Roblin, N., Tondeur, J., \& van Braak, J. (2013). Technological pedagogical content knowledge-a review of the literature. Journal of Computer Assisted Learning, 29(2), 109121. https://doi.org/10.1111/j.1365-2729.2012.00487.x

Voogt, J., \& Plomp, T. (2010). Innovative ICT-supported pedagogical practices: Results from the international study of information technology in education. Journal of Computer Assisted Learning, 26(6), 449-452. http://doi.org/10.1111/j.1365-2729.2010.00375.x

Westbrook, J., Durrani, N., Brown, R., Orr, D., Pryor, J., Boddy, J., \& Salvi, F. (2013). Pedagogy, curriculum, teaching practices and teacher education in developing countries (Final Report). University of Sussex. https://www.gov.uk/government/publications/pedagogy-curriculum-teachingpractices-and-teacher-education-in-developing-countries

Corresponding author: Medha Dalal, medha.dalal@,asu.edu

Copyright: Articles published in the Australasian Journal of Educational Technology (AJET) are available under Creative Commons Attribution Non-Commercial No Derivatives Licence (CC BY-NC-ND 4.0). Authors retain copyright in their work and grant AJET right of first publication under CC BY-NC-ND 4.0.

Please cite as: Dalal, M., Archambault, L., \& Shelton, C. (2021). Fostering the growth of TPACK among international teachers of developing nations through a cultural exchange program. Australasian Journal of Educational Technology, 37(1), 43-56. https://doi.org/10.14742/ajet.5964 